\title{
The effect of heat acclimation or acclimatisation on exercise performance and capacity in the heat: preliminary meta-analysis data
}

\author{
Tom Reeve ${ }^{1 *}$, Gary J Hodges ${ }^{2}$, Stephen S Cheung ${ }^{2}$, Christopher J Tyler $^{1}$ \\ From 15th International Conference on Environmental Ergonomics (ICEE XV) \\ Portsmouth, UK. 28 June - 3 July 2015
}

\section{Introduction}

Exercise performance and capacity are impaired in hot and humid compared to temperate conditions [1], [3] and so researchers, coaches and athletes are interested in strategies to attenuate this impairment. Heat acclimation (or acclimatisation) (HA) is one approach that may reduce the thermal strain of exercising in hot conditions and benefit exercise performance [1], [2]. This metaanalysis quantified the magnitude of effect that HA has on exercise performance and capacity in the heat, and tested whether the magnitude of effect is related to the volume or intensity of heat stress experienced.

\section{Methods}

The PubMed database was searched (09/01/15) using the first-order search terms acclimation, acclimatization, acclimatisation and adaptation and second-order search terms heat, exercise, performance, capacity and training. Using the four-stage process identified in the PRISMA statement the initial number of results $(9,369)$ was reduced to 93 . Data $(\mathrm{N}$, mean, $\mathrm{SD})$ were extracted from these articles in duplicate or triplicate. A subset of the data ( $\mathrm{n}=29$ manuscripts) are presented here; manuscripts were included if exercise performance (Time to complete a fixed amount of work: E.g., time trial) and/ or capacity (Open ended tests: E.g., Maximal aerobic power, time to exhaustion at a fixed workload), were measured and reported. All HA protocols regardless of duration, frequency, ambient conditions or exercise modality were used. Hedge's g $( \pm 95 \% \mathrm{CI})$ were calculated and correlation analyses were performed between the effect size and total HA time ( $\left.\mathrm{HA}_{\text {time }}\right)$, and HA temperature $\left(\mathrm{HA}_{\text {temp }}\right)$.

\section{Results}

The 29 manuscripts reviewed used a mean $( \pm$ SD) of 9.8 \pm 4.0 (range: $4-24$ ) HA sessions separated by $0.2 \pm 0.4$ (0 - 2) days. Total $\mathrm{HA}_{\text {time }}$ was $1055 \pm 746$ min (190 $3,120)$, and the $\mathrm{HA}_{\text {temp }}$ and $\mathrm{HA}_{\text {humidity }}$ were $39.9 \pm 5.9^{\circ} \mathrm{C}$ $(30-49)$ and $34 \pm 17 \%$ rh (14 - 87), respectively.

\section{Conclusion}

HA is an effective way to improve both exercise capacity and performance in the heat. The magnitude of the

Table 1 The effect of HA on exercise performance and capacity ( $n=7$ walking, $n=8$ running, $n=13$ cycling, $\mathrm{n}=1$ rowing)

\begin{tabular}{|c|c|c|c|c|c|c|c|}
\hline & Manuscripts & Groups & $\mathbf{N}$ & Hedges $g( \pm 95 \% \mathrm{Cl})$ & Mean $\Delta$ & $\mathrm{HA}_{\text {time }}$ & $\mathrm{HA}_{\text {temp }}$ \\
\hline Capacity & 15 & 19 & 209 & $0.60(0.40,0.81)$ & $+21 \%$ & $r=0.22^{\mathrm{NS}}$ & $r=0.11^{\mathrm{NS}}$ \\
\hline Performance & 10 & 22 & 198 & $0.58(0.37,0.79)$ & $+5.3 \%$ & $r=0.67^{* *}$ & $r=0.06^{\mathrm{NS}}$ \\
\hline
\end{tabular}

\footnotetext{
* Correspondence: T.Reeve@roehampton.ac.uk

'Department of Sport and Exercise Science, University of Roehampton,

London, UK

Full list of author information is available at the end of the article
} 
effect appears to be independent of either $\mathrm{HA}_{\text {time }}$ or $\mathrm{HA}_{\text {temp }}$ for capacity, and independent of $\mathrm{HA}_{\text {temp }}$ for performance. However, the magnitude of benefit on exercise performance may be dependent upon $\mathrm{HA}_{\text {time }}$.

\section{Authors' details}

${ }^{1}$ Department of Sport and Exercise Science, University of Roehampton, London, UK. Environmental Ergonomics Laboratory, Department of

Kinesiology, Brock University, St. Catharines, Canada.

Published: 14 September 2015

\section{References}

1. Guy JH, Deakin GB, Edwards AM, Miller CM, Pyne DB: Adaptation to Hot Environmental Conditions: an Exploration of the Performance Basis, Procedures and Future Directions to Optimise Opportunities for Elite Athletes. Sports Med 2015, 45:303-311.

2. Chalmers S, Esterman A, Eston R, Bowering K, Norton K: Short-Term Heat Acclimation Training Improves Physical Performance: A systematic Review, and Exploration of Physiological Adaptations and Application for Team Sports. Sports Med 2014, 44:971-988.

3. Maughan RJ, Shirreffs SM, Ozgunen KT, Kurdak SS, Ersoz G, Binnet MS, Dvorak J: Living, Training and Playing in the Heat: Challenges to the Football Player and Strategies for Coping with Environment Extremes. Scand J Med Sci Sport 2010, 20(suppl. 3):117-124.

doi:10.1186/2046-7648-4-S1-A122

Cite this article as: Reeve et al:: The effect of heat acclimation or acclimatisation on exercise performance and capacity in the heat: preliminary meta-analysis data. Extreme Physiology \& Medicine 2015 4(Suppl 1):A122.

\section{Submit your next manuscript to BioMed Central} and take full advantage of:

- Convenient online submission

- Thorough peer review

- No space constraints or color figure charges

- Immediate publication on acceptance

- Inclusion in PubMed, CAS, Scopus and Google Scholar

- Research which is freely available for redistribution

Submit your manuscript at www.biomedcentral.com/submit
C Biomed Central 